\title{
THE MANAGEMENT OF ORGANIZATIONAL COMMUNICATION AS A FACTOR OF SOCIALIZATION: THE MAGAZINE VIDA NOVA
}

\author{
Cantífula de Castro \\ Rádio Encontro \& Vida Nova Magazine, Mozambique \\ E-mail: padrecantifula@gmail.com
}

\begin{abstract}
Organizational communication is a key element for the survival, maintenance and consolidation of human relationships in the workplace. This research aims to understand how organizational communication is being managed in the Mozambican Catholic Vida Nova Magazine, verifying how inclusive communication contributes to maintaining good quality of the journal and a high productivity of employees. The methodology used was qualitative, with a field work that consisted of participant observation for one year, complemented by semi-structured interviews with key witnesses. The results showed that Vida Nova Magazine experiences a particular kind of participatory, dialogical and strategic communication processes, coming mainly from the spontaneity of personal relations and communication among employees rather than due to a strategic option of the management. In view of the global demands in the field of social communication, Vida Nova Magazine seeks to broaden its field of action using instrumental forms of communication, based on new technologies, as digital platforms, both social networks and the website. The socialization process of its employees is promising as it cooperates in the consolidation of personal life and is expected to have a new life with Vida Nova.
\end{abstract}

Keywords: organizational communication, collaborators socialization, community life, information processing

\section{Introduction}

The Magazine Vida Nova is a monthly periodical of a religious type, owned by the Archdiocese of Nampula and created in 1960 in the District of Meconta, Nampula Province (Northern Mozambique) and registered under number 05/GABINFO-DEPC/1994. The magazine was created by the Portuguese missionaries of Boa Nova in Nampula, which later became managed at the Anchilo Centre by the Comboni Fathers.

Even after 1975, when Mozambique achieved its national independence from the Portuguese settler, the magazine was never interrupted, even though the new state adhered to socialist ideology. Meanwhile, a censorship mechanism was activated at the governmental level, and the Magazine Vida Nova was limited in its freedom of expression in various circumstances, in line with what was happening with all the activities of the Catholic Church, considered as an ally of the former colonizer and therefore an enemy of the state (Mounier-Genoud, 2019; Nhaueleque, 2018; Thomaz, 2008). The Magazine Vida Nova has always maintained its mission, that is, to be a magazine of "Christian Formation and Information". One of its fundamental organizational aspects has always been to maintain an adequate level of communication both internally and externally, in order, on the one hand, to establish a pleasant working environment with the collaborators, and, on the other hand, to keep the subscribers and, in general, the readers constantly informed on the main themes addressed. 
PROBLEMS

OF MANAGEMENT

IN THE $21^{\text {st }}$ CENTURY

Vol. 15 , No. 2, 2020

For this reason, this research aimed to understand organizational communication as a socializing factor in Vida Nova Magazine, verifying how this contributes to maintain the good quality of the magazine and a high productivity of employees. The study, therefore, focuses on the internal aspect of communication within this organization, not touching on communication with readers and subscribers.

Communicating means allowing the flow and exchange of information, dialogue, exchange of relations and consolidation of increasingly healthy human and labor ties. When assumed in this perspective of thought, communication gains importance and becomes more valuable within organizations, taking greater prominence to improve the relationship between people in an organization and lead to a solid socialization as is the case intended for the Magazine Vida Nova.

This research made use of the qualitative methodological paradigm, focusing on the analysis of the journal's own articles and bibliography of works that address the issue of communication and organizational socialization. For the fieldwork, the same qualitative methodology was also applied in the analysis of the data obtained through participant observation and semi-structured interviews with five stakeholders among managers and collaborators of Vida Nova Magazine. The participant observation was carried out for about a year, the author being one of the journalists who daily animates the life of this magazine. The position of the researcher in relation to his subject of study had to rely on a conscious distance, since his tasks within the magazine often pushed him towards a less critical and more proactive approach, not recommended in scientific works. As there was no published research on the specific subject of this journal, a more general literature was used, which helped in the understanding of the organizational and communication dynamics internal to the object of research.

In this regard, Vida Nova Magazine has been conducted to an analysis of its organizational structure, to see if its principles and methods are managing to keep it stable and sustainable in the new economic context that is constantly developing. A very important aspect from this perspective is the promotion of effective internal communication between employees and the latter with customers.

Besides investing in the instrumental and strategic dimension, any organization needs to invest in the human communication dimension. The organizational environment is considered as a social reality experienced by people who live in it, originating the specific problem based on this research. According to an internal diagnosis, in the last three years (2017-2020), the communication that was maintained by Vida Nova Magazine for six decades did not seem to flow in the desired way to its collaborators with a view to a favorable socialization. As a matter of fact, this circumstance may have had a negative impact on the final product, that is, on the quality of the magazine. Therefore, this research sought to answer the question of how organizational communication has been driving the socialization of Vida Nova magazine's employees, and what measures were taken to overcome such stalemate.

\section{Theoretical Framework}

Human communication has followed a long road of evolution. Writings attest to the fact that human communication began in the era of polished stone when the first humans began to live in small groups. Some researchers, such as Cherry (1996), believed that all communication is linked to spoken language and to signs created by a certain social group that will use these linguistic signs to share their experiences and regulate their behavior or even as an instrument of group coexistence.

The evolution of communication is a legacy that comes to us from many peoples and ages, from the alphabetic writing of the Phoenicians, the role of the Chinese, the records of the first civilizations that left us their communicational contribution through the cave paintings that demonstrate the way of life carried out during prehistory. In Africa, what prevailed was oral tradition. It is thanks to oral communication that knowledge and other cultural values have been preserved from older generations to younger generations throughout history to the present day (Bussotti, 2015). 
In the case of Mozambique, where the adult illiteracy rate prevails to date at $45 \%$, oral communication is still an indispensable and fluent means of transmitting knowledge, especially of the local cultural heritage. For example, in traditional ${ }^{1}$ education ceremonies (initiation rites) - a characteristic practice of the people of central and northern Mozambique - the masters of ceremonies use oral communication to pass on the values and knowledge of the local cultural heritage. The traditional education of this people - which, in Northern Mozambique, finds its main moment in initiation rites, merging cultural, social and religious elements (Nhaueleque, 2012) - "takes on a more formal tone and covers education in all aspects of life. In addition to preparing young people to assume their responsibility in society, it promotes in them loyalty to community institutions" (Martinez, 2009, p. 119). From this, it is easy to conclude that human communication is in accordance with the needs of every age and culture of people. It is not a finished process; it is continuous because man exists only while communicating. This is why it is said that communication connects and integrates people and permeates the whole process of human evolution (Scheid, et al, 2019).

If this is the basis of human communication, in many cases even more so in oral cultures such as African ones, in corporate communication the approach is not the same. Torquato (1986) presented the way communication needs and functions within an organization are processed, establishing three distinct levels: i) The organizational system: referring to the internal structure of the organization, through which data concerning tasks and operations to be performed internally are transported; ii) The competitive system: linked to the channels for reaching the consumer, through which data on the organization's production activities, consumption of goods and services and the competitive structure are transported; iii) The environmental system: which refers to the means of reaching the environment in which the organization operates, involving the transportation of the social, cultural, political and economic standards by which the organization is established.

Thus Goldhaber (1999) discussed organizational communication as a complex and open system that is influenced and influences the environment through message flows that link the organizational structure to people. In this way, "it analyses the system, the functioning and the communication process between the organization and its various audiences [...] and configures the different communication modalities that permeate its activity" (Kunsch, 2006, p. 149).

Therefore, within the organization, enjoying fluid, effective and pleasant communication between employees and their superiors can generate synergy and motivation among several other benefits essential for its good functioning, as well as for the improvement of productivity. This vision is corroborated by Baldissera (2002), for whom organizational communication must transpose the forms of communication used by organizations to relate and interact with their audiences.

It is true that communication serves as an instrument and catalyst for socialization because it cooperates in shaping human behavior, both mental and physical, as well as cultural, through the experience given by social situations. Mitchell (1998) considers that socialization is a process of acculturation, communication and permanent learning. Accordingly, for Durkheim (1897), socialization enables a person to acquire the norms which define moral and ethical criteria, according to the standards of the society in which he is inserted. In the meantime, it cannot be said that there is only one form of socialization. In reality, each culture has its own "pedagogy" of socialization (Costa, 1995). It is a two-way process in which each party tries to influence and adapt to the other its own convenience and purpose. The adaptation is mutual in search of a true symbiosis between the parties. In other words, socialization is two-way and reciprocal. Also, the socialization process is often identified as a learning process, in which the organization has the pedagogical role (Mosquera, 2000).

\footnotetext{
1 It is the instructional process made up of ideas, feelings, customs and skills that are transmitted orally for some time, passing from generation to generation to members of a human society, either through verbal language or, equally, through the acts themselves. This process performs personal, social and cultural integration for the individual.
} 
PROBLEMS

OF MANAGEMENT

IN THE $21^{\text {st }}$ CENTURY

Vol. 15, No. 2, 2020

82

The classical theories of administration were based on the motivational question and a purely technical and mechanistic approach. It is noted that here the person is considered as a robot and appendix of the industrial machine, which reveals to be a prescriptive and normative approach tending towards a closed system and poor communication. For example, Taylor put more emphasis on tasks and focus on production as Fayol, put more emphasis on structure because it ensured efficiency for all parties involved, be they bodies (departments) or people (such as occupants of positions and task performers), and also defined the task of administration to foresee, organize, command, coordinate and control. The administrative functions involve the elements of the administration, i.e. the functions of the administrator (Silva, 1960).

With the advent of the Theory of Human Relations, the respect and appreciation of the person in its various dimensions has been redeemed and, automatically, communication in organizations has come to be treated as a social phenomenon, indispensable for good relationships between the different internal levels. In this respect, the Executive Director of Vida Nova Magazine ensures that within his organization, "direct and personal communication with employees on a permanent basis and also indirect communication which takes place through letters, pamphlets and telephone calls with subscribers and external collaborators flowing without a shadow of a doubt" 2 is clearly visible and practiced.

It was precisely this aspect that was investigated throughout the field work, based on a vision of human relations theory elaborated by Elton Mayo, according to which organizational communication, as an activity, happens when possibilities of negotiation, interaction, participation, recognition and dialogue are presented; when the instrumental guidelines of corporate communication lose space and it is perceived that the receiver, in the communicative process, is as important as the transmitter (Macarenco, 2006).

It is this communicational direction that was here proposed as relevant to Vida Nova Magazine, considering, according to Genelot (1998) that only through communicative acts individuals and/or groups confront their points of view and engage effectively in the purposes of the organization.

Vida Nova Magazine uses various forms of communication, both internal and marketing, to maintain permanent contact with its customers (external audiences), to provide information on how to pay for annual subscriptions or pastoral activities, to congratulate readers as part of the celebration of various events and as an advertising mechanism for its services and products.

In this way, the diversity of communication methods provides the organization (Vida Nova Magazine) with an apparatus of resources that allows greater proximity to its audiences, both internal and external. New digital communication technologies are redefining the way people relate to institutions, especially in a contemporary context where the expansion of social networks, mediated information and, above all, visual information impose challenges in the field of organizational communication.

This is the factor that, according to Bonato (2020), led the management of Vida Nova Magazine to invest "in the magazine's web page and Facebook page in addition to the Whatsapp group, hoping to contribute to greater interactivity with the magazine's readers, especially reaching the youth in cities that have access to social networks more than young people in rural areas". In addition to the printed version of Vida Nova Magazine, since the end of 2012 the magazine has been distributed online through a massive mailing list in PDF format.

Allied to this, Castells (2015) comments that the phenomenon of virtual communication in organizations is permeating the understanding of the social structure that is consolidating around networks of activities supported by Information and Communication Technologies, requiring an adequate posture of institutions according to the behavior of the publics that inhabit the networked society. The image of the organization gains importance in the external environment if within it there is an intermittent flow of communication assumed by all. Thus, nowadays, communication has become an activity responsible for the articulation of organizational relations at internal, market and institutional levels, as a univocal reality. With

2 Interview held on 10 April 2020 with the Director of Vida Nova Magazine, Bonato, in Anchilo (Nampula). 
these dimensions, the magazine Vida Nova starts to play a fundamental role, because in addition to reaching several audiences, in the course of the 60 years, it is also an opinion-former. And the very motto is deeply in keeping with this: "Magazine of Formation and Christian Information".

\section{Research Methodology}

\section{General Background}

This research had as hypothesis that the participative organizational models, accompanied by an open communication promoted by the management of the Magazine Vida Nova constitute the fundamental foundations for the good internal climate and the success and duration of the magazine.

The research focused on a methodological approach of the qualitative type, based on two disciplinary areas: on the one hand, a historical type approach, where the evolution of Vida Nova Magazine was described; on the other hand, an approach based on the sociology of organizations, with a special focus on internal communication processes. The same qualitative approach was applied both in theoretical data analysis and empirical research.

Before carrying out the actual research, an exploratory survey was carried out in the preliminary phase, contacting some people who are part of Vida Nova Magazine, among them the collaborators and managers of the organization who know the history of the magazine. Within this exploratory phase, a long process of participant observation was carried out, favored by the fact that the researcher works in the journal itself, which is the object of analysis. Having looked at the magazine's internal work from the perspective of the researcher provided valuable information, which formed the basis for formulating the semi-structured interview with key informants, which complemented the work.

The next phase of the exploratory research was the literature review, which consisted of the analysis of books and articles, among other documents. An important source in this phase was the Vida Nova Magazine itself, which provided relevant documents for the research. However, difficulties were faced, related to the lack of bibliographic material mainly from Mozambican authors who address issues around communication and socialization in organizations. This difficulty has been overcome, in part, by using the material available on the internet (articles and theses) and using several contacts from friends and well-known people who made documents available both in electronic and physical format.

\section{Participants}

In the sample selection field, the employees interviewed were chosen from a population of ten people from the magazine, based on the criteria of functions carried out within the magazine (in the sectors of Management, Secretary, Administration, Printing and Logistics), the notoriety of their work, availability and good will for the interview. In this way, the number of interviews was delimited using the saturation criterion, i.e. the information given becomes repetitive (Martins \& Bicudo, 2005).

One of the interviewers had difficulties in writing the answers and to remedy this face-toface conversation was used with the recording of the conversation which was later transcribed literally. The working methodology allowed the interviewers greater freedom in answering the questions posed.

With regard to instruments and procedures, five stakeholders (managers and employees) were interviewed. A semi-structured interview was applied to the employees who, at their request, moved by the current planetary scenario of the Coronavirus pandemic, took the printed questionnaire to answer. 
PROBLEMS

OF MANAGEMENT

IN THE $21^{\text {st }}$ CENTURY

Vol. 15 , No. 2,2020

84
Data Analysis

The collected material was favorable for the analysis and interpretation of the results according to the research objectives. The survey responses were analyzed with a focus on the main questions about communication management and the research goals. Thus, the analysis of the data consisted of the articulation of all material from the reports of the participant observation, the transcription of the interviews and the analysis of the consulted documents. Indeed, attempts were made to establish connections and relationships that would make it possible to propose new explanations and interpretations. To ensure the confidentiality of the information obtained, resulting from the interviewees' own request for anonymity, each key actor was treated with the letter "E" which corresponds to the term Employee.

\section{Research Results}

As noted above, the specialized literature divides Organizational Communication into three dimensions: Instrumental, Strategic and Human (Kunsch, 2006). Throughout the research, it was apparent that the organization, Vida Nova Magazine, favors the instrumental dimension of communication. This observation was evident throughout the participating observation work, for example listening and participating in the conversations of the magazine's collaborators, and explicitly mentioned by the interviewers. Four (4) of them were unanimous in reaffirming that there are instruments of internal communication in the Vida Nova Magazine, which manifest themselves in two ways: "through direct and personal communication with permanent collaborators and indirect communication with external ones", affirmed collaborator E4. Among the instrumental means of communication are: "Cell phones, computers, SMS, e-mails, letters, pamphlets and the magazine itself", as reported by collaborators E1, E3, E4 and E5. Such means are configured as instruments for conveying information, so they are necessary to carry out professional tasks, but in an oral culture and far from the new technologies, such tools can lead to a distancing of the collaborator from his job. Vida Nova Magazine, therefore, shows efficiency and effectiveness, which may partly explain the success and duration of its publications, this is also an extremely rare element in the Mozambican context; however, it may cause strangeness to the collaborators, who may no longer identify with the mission and values of the magazine.

If, therefore, the instrumental communication part represents a point of strength, the interviewers show some doubt about strategic communication while they also praise the human part of communication in the organization, Vida Nova. However, the current context in which the phenomenon of globalization is prevalent and with significant advances in information technology and digitalization, it is imperative to rethink the strategic dimension of communication as a way of keeping up with the demands and constant changes of contemporary society.

The E4 interviewer considers that good communication within an organization can improve its own performance and even more "workers collaborate actively and punctually respecting annual planning". In the opinion of this interviewer, this good communication motivates the employees because they perceive that they are active members and responsible of the organization. This fact is embodied in the achievement of the magazine's monthly production targets and consequent allocation to subscribers and correspondents.

This shows the materialization of the strategic dimension of the organization as it reveals the pragmatic vision of communication. In this way, it is strategically aligned, through planning and management, with the overall objectives of the organization and the principles established in relation to its mission, vision and values.

However, this view is not shared by another interviewer who considers that "there should be a greater flow of information; allow questionnaires and suggestions within the organization" (E2). According to this interviewer (an opinion that also emerged through the work of 
participant observation), strategic communication is not being widely applied by the magazine's leaders, communicating little with other members about the most important decisions of the organization. In order to fill this gap, the Vida Nova Magazine will have to increase, according to E2, the modalities that allow an authentic sense of flow in the communication process. This will allow for the participation of all collaborators in the decision-making power and in the resolution of problems that arise in the course of the work.

Despite these limitations, the interviewers confirmed that there is "a good relationship between colleagues and management as the main element" - as stated by interviewerE5. And another interviewer pointed out the existence of "correspondence in the help between workers, mutual correction and mutual counseling", as highlighted by employee E1. Therefore, the employees feel that the interpersonal relationship favors a lot for greater organizational productivity. But this seems to be the result of "personal commitment and willingness to achieve institutional goals" (E1); "mutual understanding" (E2); "comprehensive and concrete planning in the face of the various events that the current reality presents" (E4); and "identification with the common goal to be achieved and the accountability of the entire management of the magazine" (E4).

The members of the internal editorial staff make this possible through monthly, weekly and daily meetings with the operators of the magazine's printing and logistics. As a result, the employees' performance level is considered good and favorable. Nevertheless, this level of communication is yet strategic and functional to the achievement of good results in the organizational activity; but what the interviewed employees look for is a community sense of communication, which means a human form of communication.

The research revealed the presence of top-down mechanisms of communication, established by superiors to employees within the magazine Vida Nova. Above all, it is a communication in which information moves from the management to the other members of the organization following the hierarchical line. As a result, the information transmitted is basically organizational in nature, such as rules, norms, instructions, reprimands and data for performing functions.

The research also noted that the organization favors horizontal communication within the organization. It happens, above all, between employees of the same hierarchical level and the same sector, but also with other members of different departments; this makes the work within the organization become multi-sectoral, more holistic, coordinated and provides greater productivity.

Although there is a high level of organizational productivity, the interviewers are unanimous in saying that Vida Nova Magazine does not promote training to invest in employees' professional skills. This is why some consider that the skills materialize "by entrusting each operator with the task of carrying out the work with self-professionalism" (E4 \&E1). They do not hesitate to sentence that there is no mechanism of internal or external training that can serve in the professional competences of the collaborators. "I think there are no mechanisms since there are no internal or external trainings. Therefore, there is a lack of morale. Each one adapts in his own way" (E1). This idea is shared by two others, who state that "there are no courses or ongoing training. Everyone in the area in which he or she works learns by working and getting used to it over time" (E5 \&E2). Some collaborators since they started their work have never had any training other than a few days' explanation when they were inserted in their tasks and entered the organization. Another group of employees interviewed emphasizes more the "personal motivation" (E3). The existing professional shortcomings are remedied by personal findings in the course of the work "requesting full responsibility in the work sector itself. Entrusting each operator with the task of carrying out the work with professionalism and active participation" (E4). Despite these gaps that limit strategic communication, research has shown that the level of performance and skills of employees is high, demonstrating that the lack of multi-sectorial training does not affect the organization's relationships. 
PROBLEMS

OF MANAGEMENT

IN THE $21^{\text {st }}$ CENTURY

Vol. 15 , No. 2, 2020

From the participant observation it was noted that the management of Vida Nova Magazine recognizes that strategic communication is indispensable for a greater attention to the various events in the country, the search for sources and verification of the journalistic methodology used in the newsroom; greater interaction of the agents involved in the production of the magazine; invitation to a greater active participation of all collaborators in the organization and operationalization of the magazine; greater accountability of the various sectors that should not wash their hands hoping that others will solve the organizational problems.

Therefore, in order to "pursue" the demands of the current organizational situation, the internal and external audiences of Vida Nova Magazine play an outstanding role in the process of forming the organizational image because they are the true coders of the information they receive and experience through accumulated personal experience and interpersonal communication with colleagues in the organization.

Moreover, although there are strategic limits, the research showed that the interviewers perceive that the magazine and its form of communication manage to go beyond instrumental and strategic communication (which are linked to the professional part), also being interested in the person and the collaborator as such. The research revealed that the interviewers signal immeasurable advances as a result of the work done in Vida Nova Magazine. For they manage to develop personal work, in addition to primary goods; they also invest in private training in other areas of entrepreneurship, buying land and building their own homes where they welcome family members. The organization capitalizes on the humanization of the working environment as a result of the opening up of dialogic channels and greater appreciation of people. In this sense, if for some communication is a factor of greater "learning and school of life" (E5 \&E1) for others it cooperates in the articulation of family life because they manage to "buy school

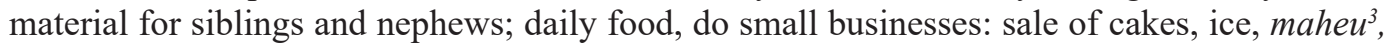
etc; invest in personal work and land" (E3 \&E2).

According to the research, there is a predominance of human communication within the organization, probably motivated by the fact that it is promoted more spontaneously by employees than planned by the highest managers. For employees are subject to "continuous interactions" (E1) and interpersonal relationships, interaction with internal and external audiences, as well as the complexity that permeates the communication that happens in them, help to overcome the merely mechanistic and instrumental vision of communication, thus incorporating a humanistic vision. This exchange of human communication has been strongly advocated and loved by Elton Mayo when he explained that organizations need to improve their relations with everyone in the organization. Workers are not machines (mechanism), but human beings, thinking and sensitive. Therefore, human interaction and teamwork improves and standardizes the context of organizational life. Within the magazine Vida Nova, it is considered that there is "interpersonal collaboration, personalized meetings in different sectors, coexistence actions and recognition of the work that is done" (E3). In this sense, and depending on the participating observation work, it is difficult to establish that the magazine Vida Nova has invested in human communication within its organization, but that it has emerged thanks to a series of interpersonal relationships between workers, which tend to reproduce the external environment, based on communitarianism and solidarity.

This important result was confirmed by the interviewers. Asked about the factors that influence internal communication, the interviewees showed that the human dimension of communication is necessary because it is a social reality experienced by people who live there. It is in this context that what has emerged in this research has become a way of understanding the communication processes in the corporate environment that needs dialogue, information exchange and participation among managers, employees and the environment. In fact, the interviewers pointed out the following internal aspects as causes of the corporatization of the human dimension of communication:

3 Traditional sweet drink made from maize flour and sugar. For its preparation, one kilogram of maize flour is mixed with three litres of water and baked until it forms porridge, about 20 minutes. 
- Openness, accessibility and availability of information to all employees;

- Authenticity in the relationship between employees ensuring effective communication and teamwork;

- Intensive prioritization of communication in terms of time, resources and everyone's alignment with the organization's goals;

- $\quad$ Search for precise information to carry out the work effectively;

- Constant learning of what is communicated;

- Mutual trust in internal relations and the fluidity of communication to be achieved;

- Concern to keep the balance between technology and personal contact.

The participant observation grid and document analysis provided the possibility of perceiving that this communicational structure originates from the genesis of the magazine itself, as well as from the external environment, which tends to reproduce the communicational mechanisms within the organization, making it more welcoming and efficient. The origin of the magazine also seems to have had a significant influence on the affirmation of the human dimension of communication among the magazine's collaborators. Since it was born as a vector of communication and information sharing for overall pastoral action, there is consequently an effort to maintain its characteristic identity in the organizational context. Thus, this model of organizational management which advocates internal communication allows for a relationship between people aimed at providing a pleasant environment of human relations and cohesion, thus being characterized as a horizontal structure, without, however, omitting the asymmetries of temperament which may exist at the internal level. Moreover, the Theory of Human Relations has unveiled labor relations giving them respect and appreciation of the person and communication is now treated as a social phenomenon.

This is how one of the interviewers believes that the interactive processes and the articulation of the balance "between technology and personal contact" (E5) contribute to the survival and achievement of the organizational objectives of the magazine. Indeed, the digital age changes on a large scale the forms of relationships and the way to produce communication.

In this way, communication in organizations becomes in itself the guarantor of the process of socialization and humanization. It is vital both in the human field and in organizational life and comprises a series of tools aimed at keeping all employees informed of what is happening in the organization. Therefore, in all aspects, knowing how to communicate is fundamental so that the message has no noise and avoids misunderstandings. The anthropological dimension assumed by communication makes us glimpse the correlation between individual and collective life mediated by communication. And, in fact, no one lives as an island without any social insertion, no matter how lonely it may be, and neither is there any society without communication. Communication is an action inherent to human nature.

\section{Discussion}

Organizational communication is an essential tool that favors the transformation of people's attitudes in the workplace. In fact, in addition to changing ideas, it should also contribute to changing the individual behavior of those around the dynamics of organizations. Communication is present in all contexts of life in society and in the corporate environment, being carried out not only through conversations, formal and informal, phone calls and meetings, but also through social and human relations every day, as well as the use of written communication tools. In fact, "it is possible to rationalize human communication as one can rationalize technical communication" (Walton, 1973, p. 39).

As stated earlier, the instrumental dimension is focused on the technical elements of communication, and aims to transmit information and enable processes (Kunsch, 2006): in short, it presupposes the efficiency of organizational communication, without looking too much at the human component. Strategic communication is also part of the elements that an organization implements to obtain greater effectiveness in its actions, involving workers more in 
PROBLEMS

OF MANAGEMENT

IN THE $21^{\text {st }}$ CENTURY Vol. 15 , No. 2, 2020

88

the decision making that the company has to take (Kunsch, 2006). Finally, the human dimension of communication characterizes "normal" communication between human beings, and can find application even in complex organizations. For example, in an organization such a dimension should be preferred, rather than suffocating collaborators with a constant bombardment of technical or instrumental communication, which usually brings the result of dehumanizing internal relationships, making work a tiring and unenthusiastic exercise (Kunsch, 2006).

This last approach was the bet of Elton Mayo's Theory of Human Relations, which was proposed to support this research. It is true that for effective communication in an organization, clarity and objectivity are required. This guarantees the progress of the processes, the execution of the activity plan and the achievement of the results of the established goals. And for communication to be effective it is important: assertiveness in the processes; engages and motivates employees; it reduces internal and external conflicts and improves the organizational climate.

The research carried out demonstrated the predominance of the three dimensions, mentioned above, within the Vida Nova Magazine. Thus, contrary to what was postulated by the classic theories of administration, for its mechanism and technicality, communication in Magazine Vida Nova is understood to be an instrument and "school of life". This circumstance is probably due to the fact that classical authors studied Western contexts, meanwhile the research here presented tried to analyze the communication flux into an African organization, even if of Catholic nature. For the mechanisms of internal communication seem highly influenced by a community approach which is present in the daily life of Vida Nova's employees, and that employees tend to reproduce inside their work relations. This process of adaptation between daily life and work could represent a new line of research for African organizations, which seem differ from Western approach to organizational communication.

\section{Conclusions}

To think about communication is to reflect about a vital process in human existence because it serves as a basis and foundation for both human life and the life of organizations. The results of the research and its intersection with the theoretical framework indicated that there is a predominance and flow of successful organizational communication in Vida Nova Magazine, although this is mainly due to mechanisms in part foreign to the organizational and communication line of the magazine. This communicational process generates in the collaborators involved in the research feelings of integration and belonging in the life of the organization, at the same time as they participate in the processes of production and organizational management. Therefore, internal communication makes it possible to establish channels that enable the agile and transparent relationship of Vida Nova Magazine with its employees. On the other hand, communication is assumed by all employees as well as between them and the organization's managers aiming to create relationship, participation, sharing and socialization in the organization. In other words, communication arises as an element of promoting understanding, understanding and mutual recognition.

In this sense, organizational communication plays an important role in the humanization and consolidation of interpersonal relationships within the magazine Vida Nova. And, as a result, it promotes not only the synergy of different work sectors, the engagement, interaction, dissemination and democratization of information, but also becomes an instrument for increasing productivity. In this sense, communication assumes the role of emancipation. Besides being based on dialogue, it allows questioning and enables the receiver to generate meaning and develop his or her autonomous system of interpretation. Moreover, the interpersonal relationship provides a pleasant and cohesive environment for a work team that shares the objectives and seeks to achieve the goals of the organization.

This type of communication directs the communicative actions with all collaborators under the same perspective, which gives attention to the internal and external environments, 
always aiming at the strategies of integration of the individual in the life of the organization from the Mission, Vision, Values and Culture of the organization. This is the social character of communication which, in turn, guarantees the well-being, good coexistence, motivation and enthusiasm of employees and individuals who train external audiences.

This is why we understand communication in Vida Nova Magazine as the cornerstone on which the organization is based and takes shape. For 60 years, Vida Nova Magazine has also been a formatter of opinion, investing in two pillars: "Formation and Christian Information". In fact, communication and humanization are the greatest challenge for those who want to reach the levels of openness of dialogical channels and greater appreciation of people. It is not enough to invest only in the instrumental and strategic dimension of communication, forgetting the human dimension. In this way, the general objective of the survey was achieved, and all the hypotheses raised were confirmed. It is true that the research faced limitations related to the lack of specialized bibliography on native organizational communication, i.e. national authors. This situation was partly resolved thanks to the information (articles, speeches, etc.) found in the magazine itself.

Despite the limitations that the research has faced, this does not mean that it has not brought relevant results that constitute a great lever and/or contribution to the area in which it fits at national and/or planetary level. Above all, this research can be taken as a starting point for researchers who are interested in this type of subjects and want to go deeper and bring new information to the country and the world.

\section{References}

Baldissera, R. (2002). Comunicação total, excelente, integrada: a (re) afirmação do óbvio [Full, excellent, integrated communication: (Re) stating the obvious]. In: Congresso Brasileiro de Ciências de Comunicação (Salvador/BA - 1 a 5 Set 2002).

Bonato, A. (2010). Mensagem por ocasião dos 50 anos da Revista Vida Nova [Message on the occasion of the 50th anniversary of Vida Nova Magazine]. Centro Catequético Paulo VI.

Bonato, A. (2020). Entrevista oral efectuada no dia 10 de Abril [Oral interview on 10 April].

Bussotti, L. (2015). Breves reflexiones sobre la historia de la comunicación africana [A short reflection on the history of African communication]. Historia y Comucación social, 20(1), 205-222. https://doi.org/10.5209/rev_HICS.2015.v20.n1.49556

Castells, M. (2015). Redes de indignação e esperança: movimentossociaisna era da internet [Networks of indignation and hope: Social movements in the internet age]. Zahar.

Cherry, C. (1996). A comunicação humana [The human communication]. Cultrix.

Costa, J. (1995). Comunicación corporativa y revolución de los servicios [Corporate communication and service revolution]. Ediciones de las Ciencias Sociales.

Durkheim, É. (1897). O Suicídio [The suicide]. Martins Fontes.

Eco, U. (1991). Tratado geral de semiótica [General treaty on semiotics]. (2 Ed). Perspectiva.

Genelot, D. (1998). Manager dans la complexité: réflexions à l'usage des dirigeants [Manager in complexity: reflections for the use of managers]. INSEP Éditions.

Goldhaber, G. M. (1991). Comunicación organizacional [Organizational communication]. Editorial Diana. Habermas, J. (1981). Teoria do Agir comunicativo [Theory of Communicative Action]. Atlas.

Kunsch, M. M. K. (2003). Planejamento de relações públicas na comunicação integrada [Public relations planning in integrated communication]. (4 ed). Summus.

Kunsch, M. M. K. (2006). Comunicação Organizacional: conceitos e dimensões dos estudos e das práticas [Organizational communication: Concepts and dimensions of studies and practices]. In: Marchiori, Marlene (Org.), Faces da cultura e da comunicação organizacional. Difusão.

Kunsch, M.M.K.(2012). As dimensões humana, instrumental e estratégica da Comunicação Organizacional: recorte de um estudo aplicado no seguimento corporativo [The human, instrumental and strategic dimensions of organizational communication: A study applied to corporate monitoring]. Intercom RBCC, 35(2), 267-289. http://dx.doi.org/10.1590/S1809-58442012000200014 
PROBLEMS

OF MANAGEMENT IN THE $21^{\text {st }}$ CENTURY Vol. 15, No. 2, 2020

Macarenco, I. (2006). Gestão com pessoas - Gestão, comunicação e pessoas [Management with people - Management, communication and people]. $\mathrm{PhD}$ Thesis in Science of Communication. São Paulo: USP. https://www.teses.usp.br/teses/disponiveis/27/27154/tde-05072009-203625/ publico/1074012.pdf

Martínez, F. L. (2009). O povo macua e a sua cultura [The Macua people and their culture]. (3 Ed.). Paulinas.

Martins, J., \& Bicudo, M. (2005). A pesquisa qualitativa em psicologia [Qualitative research in psychology]. Centauro.

Mitchel, G. D. (1998). Novo Dicionário de Sociologia [New sociology dictionary]. Rés.

Mosquera, P. (2000). Integração e Acolhimento [Integration and reception]. Capítulo X. In A. Caetano \& J. Vala, (Org), Gestão de Recursos Humanos - Contextos, Processos e Técnicas. Editora RH.

Mounier-Genoud, E. (2019). Catholicism and the making of politics in Central Mozambique, 1940-1986. Cambridge University Press.

Nhaueleque, L. A. (2012). Elementi della religione tradizionale Makhuwa. Il caso di Nampula [Elements of Makhuwa traditional religion. The case of Nampula]. In: Bussotti, L., Gatti, M., \& Nhaueleque, L. A. (Eds.). La religione nel Mozambico contemporaneo [Religion in Contemporary Mozambique]. IBIS, pp. 43-84.

Nhaueleque, L. A. (2018). Os Direitos Humanos nas Constituições de Moçambique [Human Rights in the Constitutions of Mozambique]. In: BUSSOTTI, L. \& CASTIANO, J. (Eds.), Participação da juventude e das mulheres nos processos eleitorais. [Participation of youth and women in electoral processes] (pp. 105-126). Minerva/OXFAM.

Scheid, D., Machado, J., \& Pérsigo, P. (Eds.) (2019). Tendências em comunicação organizacional [Tendencies in organizational communication]. USFM. https://www.ufsm.br/app/uploads/ sites/330/2019/10/Livro-Tend\%C3\%AAncias.pdf

Silva, B. (1960). Taylor e Fayol. Rio de Janeiro: Fundação Getúlio Vargas. https://bibliotecadigital.fgv.br/ dspace/bitstream/handle/10438/11988/44_000020845.pdf

Simon, H. (1965). Comportamento administrativo [Administrative behavior]. FGV.

Thayer, L. (1972). Princípios de comunicação na administração: comunicação e sistemas de comunicação na organização da administração e relações internas [Communication principles in management: Communication and communication systems in management organization and internal relations]. Atlas.

Thomaz, O. (2008). "Escravos sem dono": a experiência social dos campos de trabalho em Moçambique no período socialista ["Ownerless slaves": The social experience of the forced labor camps in Mozambique during socialism]. Revista de Antropologia, 5(1), 177-214. http://taurus.unicamp.br/ bitstream/REPOSIP/106048/1/2-s2.0-84859519439.pdf

Torquato, F. G. (1986). Comunicação empresarial, comunicação institucional: conceitos, estratégias, sistemas, estrutura, planejamentos e técnica [Business communication, institutional communication: Concepts, strategies, systems, structure, planning and technique]. Summus.

Walton, R.E. (1973). Quality of working life: What is it? Sloan management: Editora Vozes.

Received: October 10, 2020

Accepted: December 03, 2019 
Cite as: Castro, C. de (2020). The management of organizational communication as a factor of socialization: The magazine Vida Nova. Problems of Management in the $21^{\text {st }}$ Century, 15(2), 79-91. https://doi.org/10.33225/pmc/20.15.79 